\title{
Comparison of Three Protocols to Preserve Leptospira spp. in Cat Urine for Efficient DNA Extraction and PCR Amplification*
}

\author{
Carolina Trochmann Cordeiro', Jéssica Damiana Marinho Valente' ${ }^{1}$, Leonardo Gaspareto dos Santos ${ }^{1}$, \\ Rafael Felipe da Costa Vieira², Thállitha Samih Wischral Jayme Vieira² \& Simone Tostes de Oliveira Stedile ${ }^{2}$
}

\begin{abstract}
Background: The pathogenic leptospira infection in mammalian species can cause a range of acute or chronic manifestations and may result in a carrier state. Previous studies have suggested that cats were resistant to acute leptospirosis however, the description of some clinical cases suggests that Leptospira spp. may also be pathogenic to this species. Recent studies have shown that leptospires may be shed in the urine of infected cats. Endogenous substances present in urine may inhibit PCR and allow leptospires to evade detection. This study aims to compare three protocols for sample processing to optimize the detection of pathogenic leptospires in cat urine.
\end{abstract}

Materials, Methods \& Results: Three protocols to optimize the detection of pathogenic leptospires in cat urine were tested. Aliquots of standard concentration of L. interrogans serovar Canicola culture were added to urine samples to achieve concentrations of $1 \times 10^{5}$ to $1 \times 10^{2}$ leptospires $/ \mathrm{mL}$ for each protocol. In protocols $\mathrm{A}$ and $\mathrm{B}$ the urine was neutralized by the addition of phosphate-buffered saline (PBS), $\mathrm{pH} 7.4$, in a proportion of 1 PBS: 2.5 urine (v/v). In protocol A, PBS was added to neutralize the urine $\mathrm{pH}$ for the leptospiral organisms immediately after addition of leptospires. In protocol B, PBS was added just before DNA extraction. In protocol C, no PBS was added. DNA extraction was performed at 4, 24 and $48 \mathrm{~h}$ after addition of the leptospires using a modified protocol. Samples were incubated at $37^{\circ} \mathrm{C}$ for $10 \mathrm{~min}$. Samples were then centrifuged $(850 \mathrm{~g})$ for $15 \mathrm{~min}$, at $25^{\circ} \mathrm{C}$. The supernatants were transferred to another tube, and the pellets were discarded. The supernatants were centrifuged $(16060 \mathrm{~g})$ for $20 \mathrm{~min}$ at $4^{\circ} \mathrm{C}$. The supernatants were then discarded, and the pellets resuspended and washed with $1000 \mu \mathrm{L}$ of PBS. All the samples were centrifuged at $16060 \mathrm{~g}$ for an additional 20 min at $25^{\circ} \mathrm{C}$. The supernatants were discarded and the pellets were resuspended in $100 \mu \mathrm{L}$ of PBS and incubated at $94^{\circ} \mathrm{C}$ for $10 \mathrm{~min}$. DNA was stored at $-20^{\circ} \mathrm{C}$ until the molecular analysis. The PCR detection limit was evaluated. In samples from protocol A, leptospires were detected in concentrations up to $1 \times 10^{3}(4 \mathrm{~h})$ and $1 \times 10^{4}(24$ and $48 \mathrm{~h})$. In protocol C, leptospires were detected in concentrations up to $1 \times 10^{4}(4 \mathrm{~h})$ and $1 \times 10^{5}(24$ and $48 \mathrm{~h})$. No leptospiral DNA was detected in samples from protocol B.

Discussion: Leptospires are sensitive to acid conditions, at $\mathrm{pH} 6.8$ or lower and the urine $\mathrm{pH}$ of cats may vary from 5 to 7. In the present study, we found best results for DNA amplification with the addition of PBS immediately after urine collection (protocol A). Previous studies have shown the importance of neutralizing urine samples immediately after collection to avoid loss of bacterial DNA during the extraction process. However, protocols B and C may be an alternative in clinical practice, when PBS cannot be added immediately after collection. The delay after urine collection before DNA extraction is one more factor that may interfere with the PCR sensitivity. This was observed in the samples from protocol A, because although these samples were neutralized immediately, there was a 10-fold decrease in the detection limit of the test at 24 and $48 \mathrm{~h}$. Leptospires rapidly lose their integrity in urine and the detection limit declines considerably over time, so prompt extraction is essential. These results show that the in-house method of preserving cat urine is useful to maintain the viability of leptospiral DNA extraction. In addition, this study highlights the importance of neutralizing urine samples immediately after collection and the need for prompt DNA extraction to improve PCR detection limit. However, if PBS cannot be added to the collected sample immediately, it is better to process the sample without PBS and extract DNA as soon as possible to minimize the risk of false-negative results.

Keywords: feline, leptospires, leptospirosis, molecular diagnostic.

*Article based on a Thesis submitted by the senior author in partial fulfillment of requirements for the Master's Degree. 'Programa de Pós-graduação em Ciências Veterinárias \& ${ }^{2}$ Departamento de Medicina Veterinária, Universidade Federal do Paraná (UFPR), Curitiba, PR, Brazil. CORRESPONDENCE: S.T.O. Stedile [tostesimone@gmail.com]. Departamento de Medicina Veterinária - UFPR. Rua dos Funcionários n. 1540. CEP 80035-050 Curitiba, PR, Brazil. 


\section{INTRODUCTION}

Leptospirosis is a zoonotic disease caused by pathogenic leptospira species. The infection in mammalian species can cause a range of acute or chronic manifestations and may result in a carrier state for which the duration varies considerably between species [5]. Previous studies in cats have suggested that they are resistant to acute leptospirosis; however, the description of some clinical cases suggests that Leptospira spp. may also be pathogenic to this species [1-3,9,11,12]. Cats may shed leptospires intermittently in their urine for several weeks after experimental or natural infection $[4,6,8,12,13]$. These findings suggest that cats are a potential source of infection for human beings and others animals [12].

The diagnosis of leptospirosis in urine is performed by dark-field examination to identify leptospires or by PCR to detect leptospiral DNA. PCR is useful for rapid detection and provides high sensitivity, but sample processing has critical points and must be adjusted depending on the tissue, fluid, and species being tested [10]. Some DNA purification steps are also necessary before performing PCR amplification, because DNA degradation may lead to false negative results [10]. These steps increase the cost of the test because they require the use of expensive kits to purify DNA. In cats, some studies have been performed using commercial kits $[4,6,12,13]$, but the extraction of DNA using in-house methods has not yet been reported.

The aim of this study is to compare three protocols for sample processing to optimize the detection of pathogenic leptospires in cat urine by in-house DNA extraction and further PCR testing.

\section{MATERIALS AND METHODS}

\section{Bacterial strain}

Leptospira interrogans serogroup Canicola, serovar Canicola, strain Hond Utrecht IV (CLEP 00003 FIOCRUZ) was used. The concentration of leptospires in a 2-week-old culture in liquid EllinghausenMcCullough/Johnson-Harris medium was determined using a Petroff-Hauser Counting Chamber. The final concentration was $1 \times 10^{9}$ leptospires $/ \mathrm{mL}$.

\section{Urine mixed with leptospires}

Urine was collected by cystocentesis from a domestic shorthair cat with a strictly indoor lifestyle. The cat had 1-year-old, and no pre-existing illness nor was it receiving any medication. The urine $\mathrm{pH}$ was 6 .

Aliquots of leptospire culture medium were added to aliquots of urine to achieve concentrations of $1 \times 10^{5}$ to $1 \times 10^{2}$ leptospires $/ \mathrm{mL}$ for each protocol. Leptospires were added to all the samples at the same time (Figure 1).

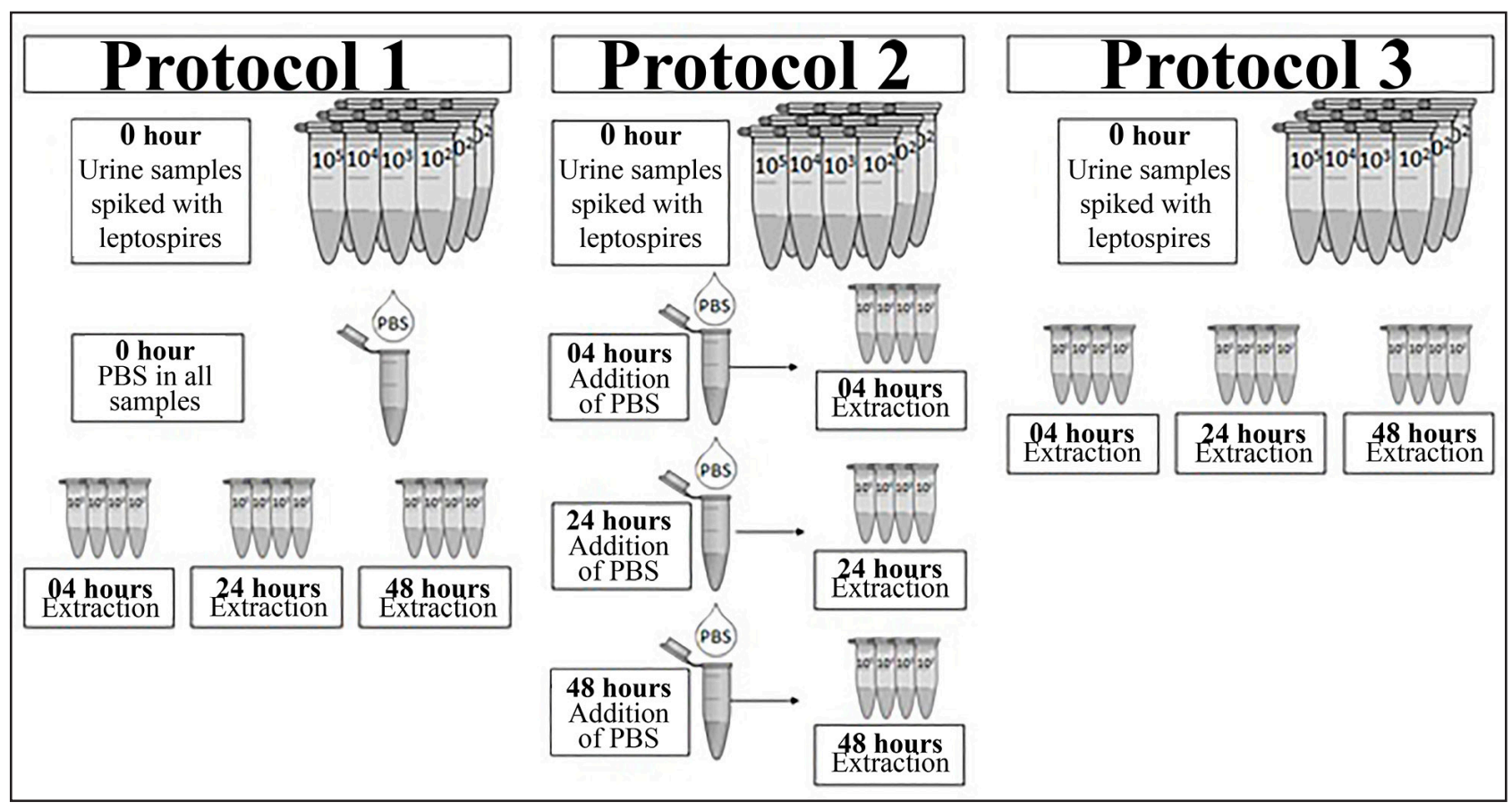

Figure 1. Demonstration of steps. Urine samples were spiked, neutralized and DNA was extracted according to three different protocols to compare the limits of PCR for detection of leptospiral DNA in cat urine. 


\section{Neutralization of urine}

In all the three protocols the urine samples contained dilutions of $1 \times 10^{5}$ to $1 \times 10^{2}$ leptospires $/ \mathrm{mL}$. In protocols $A$ and $B$ the urine was neutralized by the addition of phosphate-buffered saline (PBS), $\mathrm{pH} 7.4$, in a proportion of 1 PBS: 2.5 urine $(\mathrm{v} / \mathrm{v})$. In protocol A, PBS was added to the sample immediately after urine collection and addition of the leptospires. In protocol B, PBS was added just prior to DNA extraction. In protocol C, PBS was not added (Figure 1). All samples were refrigerated at $4^{\circ} \mathrm{C}$ until DNA extraction was performed.

\section{DNA extraction}

DNA was extracted from urine samples at 4, 24 and $48 \mathrm{~h}$ using a modified protocol [10]. Samples were incubated at $37^{\circ} \mathrm{C}$ for $10 \mathrm{~min}$, to eliminate amorphous sediment. Samples were then centrifuged $(850 \mathrm{~g})$ for $15 \mathrm{~min}$, at $25^{\circ} \mathrm{C}$. The supernatants were transferred to another tube, and the pellets were discarded to remove epithelial cells, leukocytes and crystals commonly present in urine. The supernatants were centrifuged $\left(16060 \mathrm{~g}\right.$ ) for $20 \mathrm{~min}$ at $4^{\circ} \mathrm{C}$. The supernatants were then discarded, and the pellets resuspended and washed with $1000 \mu \mathrm{L}$ of PBS. All the samples were centrifuged at $16060 \mathrm{~g}$ for an additional $20 \mathrm{~min}$ at $25^{\circ} \mathrm{C}$. The supernatants were discarded and the pellets were resuspended in $100 \mu \mathrm{L}$ of PBS and incubated at $94^{\circ} \mathrm{C}$ for $10 \mathrm{~min}$. DNA was stored at $-20^{\circ} \mathrm{C}$ until the molecular analysis.

\section{$P C R$}

Previously described primers targeting the lipL32 gene (242 bp) of pathogenic leptospira species were used LIPL3245Fw (5'-AAG CAT TAC CGC TTG TGG TG-3') and LIPL32286Rv (5'-GAA CTC CCA TTT CAG CGA TT-3'). PCR was performed in a total reaction mixture of $25 \mu \mathrm{L}$ containing $5 \mu \mathrm{L}$ of DNA template for the ampli- fication, 1x PCR buffer1, $1.5 \mathrm{mM}$ of $\mathrm{MgCl}_{2}, 0.2 \mu \mathrm{M}$ of each desoxynucleoside triphosphate (dATP, dCTP, dGTP, dTTP), 1.0 U of Taq DNA polymerase (Recombinant ${ }^{\circledR}$ Taq DNA Polymerase) $)^{2}$ and $0.2 \mu \mathrm{M}$ of each primer.

PCR was performed using a thermocycler (SimpliAmpTM Thermal Cycler) $^{3}$. The amplification protocol consisted of $3 \mathrm{~min}$ at $94^{\circ} \mathrm{C}$ for initial denaturation, 35 cycles of amplification (denaturation at $94^{\circ} \mathrm{C}$ for $45 \mathrm{~s}$, annealing at $52^{\circ} \mathrm{C}$ for $45 \mathrm{~s}$ and extension at $72^{\circ} \mathrm{C}$ for $45 \mathrm{~s}$ and the final extension of $5 \mathrm{~min}$ at $72^{\circ} \mathrm{C}$. Each run included a negative control (ultrapure water), DNA extraction negative control and a positive control (DNA extracted from leptospire cultures). The amplified PCR products were subjected to gel electrophoresis in $1.5 \%$ agarose gels for $1 \mathrm{~h}$ at $100 \mathrm{~V}$, followed by ethidium bromide staining $(0.5 \mu \mathrm{g} / \mathrm{mL}$ TBE buffer). Visualization and photography of the bands of the expected size products were performed under UV light (L-PIX-HE ${ }^{\natural}$ using the software L-PIX-IMAGE ${ }^{\circledR 4}$.

The detection limit of the assay was measured by testing tenfold dilutions of fresh $L$. interrogans s. Canicola culture $\left(10^{8}\right.$ to $10^{1}$ leptospires $\left./ \mathrm{mL}\right)$ in sterile PBS solution. DNA was further extracted and PCR performed.

\section{RESULTS}

The lower limit of detection was defined as the smallest number of organisms in a sample that could be detected by the PCR assay. Amplification of lesptospiral DNA was efficient up to $10^{-3}(5$ copies/ $\mu \mathrm{L})$ dilutions of the starting template.

In protocol A, leptospiral DNA was detected in dilutions up to $1 \times 10^{3}$ when DNA was extracted at $4 \mathrm{~h}$, and up to $1 \times 10^{4}$ at 24 and $48 \mathrm{~h}$. In protocol B, no leptospiral DNA was detected. In protocol C, leptospires were detected in dilutions up to $1 \times 10^{4}$ when DNA was extracted at $4 \mathrm{~h}$, and up to $1 \times 10^{5}$ at 24 and $48 \mathrm{~h}$ (Table 1 ).

Table 1. Detection limits of leptospiral DNA by PCR in cat urine comparing three protocols for sample storage.

\begin{tabular}{cccccc}
\hline Protocol & Hours for extraction & Dilution $1 \times 10^{5}$ & Dilution $1 \times 10^{4}$ & Dilution $1 \times 10^{3}$ & Dilution $1 \times 10^{2}$ \\
\hline \multirow{2}{*}{ A } & 4 & + & + & + & - \\
& 24 & + & + & - & - \\
\hline & 48 & + & - & - & - \\
B & 4 & - & - & - & - \\
& 24 & - & - & - & - \\
\hline & 48 & - & + & - & - \\
C & 4 & + & - & - & - \\
& 24 & + & - & - & - \\
\hline
\end{tabular}




\section{DISCUSSION}

The PCR assay used here was able to detect 5 copies/ $\mu \mathrm{L}$ of leptospiral DNA. Previous studies have reported detection limits of 4.15 copies/reaction in cats [12] and 50 copies/reaction in humans [10] both using G1 and G2 and B64-I/B64-II primers. The primer sets used in this study are not only highly sensitive but have another advantage; in contrast to PCRs using G1 and G2 and B64-I/B64-II primers, the pair of primers used in this study does not require a reaction multiplex or 2 single-reaction to include the genomospecie L. kirshneri, which contains serogroups commonly found in animals (Australis, Autumnalis, Bataviae, Canicola, Cynopteri, Djasiman, Grippotyphosa, Hebdomadis, Icterohaemorrhagiae, Pomona) [5].

Leptospires are sensitive to acid conditions, at $\mathrm{pH} 6.8$ or lower [5] and the urine $\mathrm{pH}$ of cats may vary from 5 to 7 [7]. In the present study, we found best results for DNA amplification with the addition of PBS immediately after urine collection (protocol A). Previous studies have shown the importance of neutralizing urine samples immediately after collection to avoid loss of bacterial DNA during the extraction process [10]. However, protocols B and C may be an alternative in clinical practice, when PBS cannot be added immediately after collection.

However, when PBS was added immediately prior to extraction (protocol B), no leptospiral DNA was detected. This may be explained by two aggravating factors: the initial lack of neutralization plus the increase in the final dilution of the sample. During the detection limit assays, it was observed that after 4 $h$ in contact with acid urine ( $\mathrm{pH}$ 6), leptospiral DNA could not be detected by PCR in concentrations lower than $1 \times 104$ in the samples without PBS (protocol C). This indicates a 10-fold decrease in detection limit, compared to the samples of protocol A.
The delay after urine collection before DNA extraction is one more factor that may interfere with the PCR sensitivity. This was observed in the samples from protocol A, because although these samples were neutralized immediately, there was a 10 -fold decrease in the detection limit of the test at 24 and 48 h. Leptospires rapidly lose their integrity in urine and the detection limit declines considerably over time, so prompt extraction is essential [10].

\section{CONCLUSIONS}

These results show that the in-house method of preserving cat urine is useful to maintain the viability of leptospiral DNA extraction. In addition, this study highlights the importance of neutralizing urine samples immediately after collection and the need for prompt DNA extraction to improve PCR detection limit. However, if PBS cannot be added to the collected sample immediately, it is better to process the sample without PBS and extract DNA as soon as possible to minimize the risk of false-negative results.

\section{MANUFACTURERS \\ ${ }^{1}$ Applied Biosystems. São Paulo, SP, Brazil. \\ ${ }^{2}$ Invitrogen. Carlsbald, CA, USA. \\ ${ }^{3}$ Applied Biosystems. Foster City, CA, USA. \\ ${ }^{4}$ Loccus Biotecnologia. Cotia, SP, Brazil.}

Funding. This research was supported financially by the "Chamada Universal MCTI/CNPq n01/2016".

Acknowledgments. CNPq (Conselho de Desenvolvimento Cientifico e Tecnológico) supported this study. "Centro de diagnóstico Marcos Enrietti" for the donation of Leptospira interrogans strains used in this research.

Ethical approval. This study was approved by the Ethics Committee on Animal Research from Universidade Federal do Parana (protocol number 057/2015).

Declaration of interest. The authors report no conflicts of interest. The authors alone are responsible for the content and writing of this manuscript.

\section{REFERENCES}

1 Agunloye C.A. \& Nash A.S. 1996. Investigation of possible leptospiral infection in cats in Scotland. Journal of Small Animal Practice. 37(3): 126-129

2 Arbour J., Blais M-C., Carioto L. \& Sylvestre D. 2012. Clinical Leptospirosis in Three Cats (2001-2009). Journal of the American Animal Hospital Association. 48(4): 256-260.

3 Beaudu-lange C. \& Lange E. 2014. Unusual clinical presentation of leptospirosis in a cat. Revue Vétérinaire Clinique. 49(3): 115-122.

4 Chan K.W., Hsu Y.H., Hu W.L., Pan M.J., Lai J.M., Huang K.C. \& Chou S.J. 2014. Serological and PCR detection of feline leptospira in southern Taiwan. Vector borne zoonotic diseases. 14(1): 118-123. 
5 Faine S., Adler B., Bolin C. \& Perolat P. 1999. Leptospira and leptospirosis. 2nd edn. Melbourne: MedScience, 272p.

6 Fenimore A., Carter K. \& Lunn K.F. 2012. Detection of Leptospiruria in Shelter cats in Colorado. [Abstract ID-3] In: ACVIM Forum 2012 (New Orleans, USA). Journal of Veterinary Internal Medicine. 26(3): 783.

7 Holt P.E. 2008. Urological disorders of the dog and cat - investigation, diagnosis and treatment. London: Manson Publishing Ltd., 176p.

8 Larsson C.E., Rosa C.A.S., Larsson M.H., Birgel E.H., Fernandes W.R., Paim G.V. \& Santa Rosa C.A. 1985. Laboratory and clinical features of experimental feline leptospirosis. International Journal of Zoonoses. 12(2): 111119.

9 Lévesque B., De Serres G., Higgins R., D’Halewyn M.A., Artsob H. \& Grondin J., Major M., Garvie M. \& Duval B. 1995. Seroepidemiologic study of three zoonoses (leptospirosis, Q fever, and tularemia) among trappers in Québec, Canada. Clinical and Diagnostic Laboratory Immunology. 2(4): 496-498.

10 Lucchesi P.M.A, Arroyo G.H., Etcheverría A.I., Parma A.E. \& Seijo A.C. 2004. Recommendations for the detection of Leptospira in urine by PCR. Revista da Sociedade Brasileira de Medicina Tropical. 37(2): 131-134.

11 Millán J., Candela M.G., López-Bao J.V., Pereira M., Jiménez M.A. \& León-Vizcaíno L. 2009. Leptospirosis in wild and domestic carnivores in natural areas in Andalusia, Spain. Vector Borne Zoonotic Diseases. 9(5): 549-554.

12 Rodriguez J., Blais M.C., Lapointe C., Arsenault J., Carioto L. \& Harel J. 2014. Serologic and urinary PCR survey of leptospirosis in healthy cats and in cats with kidney disease. Journal of Veterinary Internal Medicine. 28(2): 284-293.

13 Weis S., Rettinger A., Bergmann M., Llewellyn J.R., Pantchev N., Straubinger R.K. \& Hartmann K. 2016. Detection of Leptospira DNA in urine and presence of specific antibodies in outdoor cats in Germany. Journal of Feline Medicine and Surgery. 19(4): 470-476. 